\title{
ІНСТИТУЦЙНИЙ ДИЗАЙН МАКРОФІНАНСОВОЇ БЕЗПЕКИ ДЛЯ СТАБІЛІЗАЦІЇ НАЦІОНАЛЬНОЇ ЕКОНОМІКИ
}

\author{
Радіонова Ірина Федорівна, \\ доктор економічних наук, професор, \\ ДВНЗ Київський національний університет імені Вадима Гетьмана, \\ ВНЗ «Університет економіки та права «КРОК», \\ ORCID: https://orcid.org/0000-0002-0941-2867,
}

\begin{abstract}
Мальковська Юлія Борисівна, магістр публічного управління та адміністрування, аспірантка PhD програми «Публічне управління та адміністрування», ДВНЗ Київський національний університет імені Вадима Гетьмана, ORCID: https://orcid.org/0000-0001-6052-0639
\end{abstract}

Анотація. Розділ присвячено науковій та прикладній для публічного управління економікою проблемі формування національного інституційного дизайну в спеціальній сфері. Йдеться про сферу макрофінансової стабільності (безпеки). Важливість цієї сфери $є$ доведеною (верифікованою) в Україні та в інших країнах. Тому для обгрунтування висновків і управлінських пропозицій аналізувався не лише стан публічного управління цією сферою в Україні, а й досвід регулювання макрофінансових дисбалансів у ЄС. Результатом дослідження стала схема (певний алгоритм) дій з формування дизайну макрофінансової безпеки для української економіки та суспільства.

Ключові слова: макрофінансова стабільність (безпека), табло макрофінансових дисбалансів, інституційний дизайн, матриця взаємодії інститутів влади.

Актуальність дослідження проблеми формування інституційного дизайну макрофінансової безпеки для української економіки та суспільства пояснюється принаймні двома обставинами. По-перше, макрофінансовій сфері національної економіки бракує стабільності, а нагромаджені у ній дисбаланси є загрозливими для іiі цілісності. Подруге, макрофінансові дисбаланси не стали об'єктом спеціального моніторингу, аналізу, коригування, запобігання органами публічної (державної) влади. Це виявляється у несформованості правил, алгоритмів, процедур, стимулів, санкцій, каналів взаємодії урядів зі спільнотами та суспільством тощо. Отже, йдеться про відсутність того, що називається інституційним дизайном. Останній покликаний забезпечувати оцінювання, запобігання, коригування макрофінансових диспропорцій. А макрофінансова стабільність у такий спосіб 3 побажання урядів перетворюється на економічну дійсність. 
Метою цього дослідження є обгрунтування певного алгоритму дій 3 формування інституційного дизайну, покликаного протидіяти формуванню й поглибленню макрофінансових дисбалансів в українській економіці.

Наукова й управлінська проблема формування інституційного дизайну макрофінансової безпеки передбачає відповіді на декілька питань. Передусім постає питання про власне зміст поняття «макрофінансова безпека». Це випливає зі зрозумілої логіки міркувань: оскільки макрофінансова безпека $є$ змістом (і метою) інституційного дизайну, остільки між змістом та формою має досягатися відповідність. Останнє передбачає якомога точнішу ідентифікацію змісту. Не менш важливим $є$ й питання про зміст поняття «інституційний дизайн», про необхідні складники (елементи) сформованого дизайну та про особливості інституційного дизайну в українській економіці, з огляду на існуючі економічні дисбаланси та чинну систему публічного управління. Досліджуючи основну проблему, ми намагатимемося частково відповідати й на ці питання.

Наша логіка дослідження спирається на такі два припущення.

Перше: макрофінансова сфера може й має бути виокремлена як певний сегмент національної економіки з властивими їй пропорціями (балансами), відповідно - показниками для оцінювання та інститутами публічної влади для моніторингу, контролю і коригування.

Друге: поняття (явища) «стабільність» та «безпека» є щільно пов'язаними, а, можливо, й синонімічними. Маємо на увазі той незаперечний факт, що існування макрофінансової стабільності означає перебування економіки у безпечному стані. I, навпаки, макрофінансова безпека, що виявляється у відсутності надмірних дисбалансів, одночасно означає існування макрофінансової стабільності. Якщо поняття «макрофінансова стабільність» та «макрофінансова безпека» і мають відмінності, то вони не $є$ принципово важливими для нашого дослідження.

Термін «макрофінансова» застосовується не лише в контексті безпеки, а й в інших контекстах, а саме: «макрофінансові диспропорції» [1], «макрофінансова стабільність» [2], «макрофінансовий аналіз» [3] тощо. Активність уживання цих термінів зростала після світової фінансової кризи 2008 - 2010 рр.

Аналіз уживання згаданих пов'язаних понять дає підстави для висновку про існування двох тлумачень, відповідно, двох застосувань терміна «макрофінансове»: спрощеного (загального) та більш складного (конкретизованого).

Спрощений варіант використання терміна «макрофінансове», наприклад, знаходимо у фундаментальній роботі британських та американських дослідників, присвяченій оптимізації політики. У 
дослідженні йдеться про макрофінансову стабільність як таку, що передбачає відповідність фінансової системи загальному стану всієї економіки [4]. Фактично, «макрофінансове» тлумачиться як взаємодія (узгодження) фінансового та макроекономічного.

Складніший (більш конкретизований) варіант застосування терміна «макрофінансове» пов'язаний з різними алгоритмами (методиками) оцінювання дисбалансів національних економік. Ідеться передовсім про встановлений для країн ЄС перелік (Табло) показників та їх орієнтовних порогових значень для оцінювання дисбалансів i застосування процедури їх подолання («MIP Scoreboard»). Попри те, що дисбаланси називаються в офіційному документі $\mathrm{CC}$ макроекономічними (Macroeconomic imbalances procedure - MIP), їx значна частина, незаперечно, має «подвійну» макрофінансову природу. Про це свідчить власне зміст показників для оцінювання стану національних економік $\mathrm{CC}$, поданий у табл. 1 .

Таблиия 1

Індикатори для виявлення макроекономічних дисбалансів у країнах ЄС 2011 та 2018 pp.

\begin{tabular}{|c|c|c|}
\hline $\begin{array}{c}\text { Сфера } \\
\text { дисбалансів } \\
\end{array}$ & Ключові показники & $\begin{array}{c}\text { Рекомендовані } \\
\text { порогові значення }\end{array}$ \\
\hline \multicolumn{3}{|c|}{ Спільне для MIP Scoreboard у 2011 та 2018 рp. } \\
\hline \multirow{5}{*}{$\begin{array}{l}\text { Зовнішня/ } \\
\text { реалізації } \\
\text { конкурентної } \\
\text { спроможності } \\
\text { країни }\end{array}$} & $\begin{array}{l}\text { 1. Середня за } 3 \text { останні роки величина сальдо } \\
\text { рахунку поточних операцій (у\% до ВВП) }\end{array}$ & від $-4 \%$ до +6\% ВВП \\
\hline & $\begin{array}{l}\text { 2. Чиста міжнародна інвестиційна позиція (\% } \\
\text { до ВВП) }\end{array}$ & $-35 \%$ ВВП \\
\hline & $\begin{array}{l}\text { 3. Зміна за } 3 \text { останні роки реального ефективного } \\
\text { обмінного курсу (РЕОК), обчисленого на основі } \\
\text { дефлятора ВВП відносно валют } 35 \text { (у МІР } \\
\text { 2011) /42 (у МІР 2018) розвинених країн }\end{array}$ & $\begin{array}{l}\text { від }+5 \% \text { до -5\% для } \\
\text { країн-членів Єврозони; } \\
\text { від }+11 \% \text { до }-11 \% \text { для } \\
\text { всіх інших країн ЄС }\end{array}$ \\
\hline & $\begin{array}{l}\text { 4. Зміна за останні } 5 \text { останніх років частки } \\
\text { експорту країни у світовому експорті (у \%) }\end{array}$ & $6 \%$ \\
\hline & $\begin{array}{l}\text { 5. Зміна за } 3 \text { останні роки номінальної вартості } \\
\text { робочої сили в розрахунку на одиницю } \\
\text { продукції }(\%)\end{array}$ & $\begin{array}{l}\text { +9\% для країн-членів } \\
\text { Сврозони; } \\
+12 \% \text { для всіх інших } \\
\text { країн ЄС }\end{array}$ \\
\hline \multirow{5}{*}{ Внутрішня } & $\begin{array}{l}\text { 6. Річна дефльована (реальна) зміна } \\
\text { гармонізованого індексу цін на житло (\%) }\end{array}$ & $+6 \%$ \\
\hline & $\begin{array}{l}\text { 7. Кредитування приватного сектору } \\
\text { (нефінансових корпораиій, домогосподарств, } \\
\text { некомериійних організацій) на консолідованій } \\
\text { основі (\% ВВП) }\end{array}$ & $\begin{array}{l}15 \%(\mathrm{y} \text { MIP 2011) / } \\
14 \% \text { ВВП (y MIP } \\
2018)\end{array}$ \\
\hline & $\begin{array}{l}\text { 8. Заборгованість приватного сектору } \\
\text { (вартість позик і цінних паперів, окрім акцій), } \\
\text { обчислена на консолідованій основі (\% ВВП) }\end{array}$ & $\begin{array}{l}160 \% \text { (y MIP 2011)/ } \\
133 \% \text { ВВП (y MIP } \\
2018)\end{array}$ \\
\hline & 9. Загальний державний борг (\% ВВП) & $60 \%$ ВВП \\
\hline & $\begin{array}{l}\text { 10. Середній за } 3 \text { останні роки рівень } \\
\text { безробіття (\%) }\end{array}$ & $10 \%$ \\
\hline
\end{tabular}


Продовження табл. 1

\begin{tabular}{|c|c|c|}
\hline \multicolumn{3}{|c|}{ Особливе (додаткове) у MIP Scoreboard у 2018 р. } \\
\hline Внутрішня & $\begin{array}{l}\text { Річна зміна боргових зобов'язань фінансового } \\
\text { сектору на неконсолідованій основі (\%) }\end{array}$ & $16,5 \%$ \\
\hline \multirow{3}{*}{$\begin{array}{l}\text { Сфера } \\
\text { зайнятості }\end{array}$} & $\begin{array}{l}\text { Зміна за } 3 \text { останні роки рівня активності } \\
\text { населення віком від } 15 \text { до } 64 \text { років }\end{array}$ & $-0,2$ пункти \\
\hline & $\begin{array}{l}\text { 3міна за } 3 \text { останні роки рівня довготермінового } \\
\text { безробіття (у \%) активного населення віком від } \\
15 \text { до } 74 \text { років }\end{array}$ & 0,5 пункти \\
\hline & $\begin{array}{l}\text { Зміна за } 3 \text { останні роки рівня безробіття молоді } \\
\text { віком від } 15 \text { до } 24 \text { років }\end{array}$ & 2 пункти \\
\hline
\end{tabular}

Джерело: розроблено авторами на основі [5; 6].

Наведена аналітична таблиця віддзеркалює інформацію про показники для оцінювання стабільності національних економік та нормативи для визначення міри відхилення від безпечних меж. Якщо документами 2011 р. передбачалося використання 10-х показників, 3 яких 6 мали очевидну макрофінансову природу, то нині їх загальна кількість зросла до 14-х, з яких 7 можуть тлумачитися як макрофінансові. До показників «подвійного» - макроекономічного й, водночас, фінансового змісту - належать, на наш погляд, такі:

- середня за 3 останні роки величина сальдо рахунку поточних операцій (у \% до ВВП);

- чиста міжнародна інвестиційна позиція (\% до ВВП);

- зміна за 3 останні роки реального ефективного обмінного курсу (РЕОК), обчисленого на основі дефлятора ВВП відносно валют розвинених країн;

- кредитування приватного сектору, оцінене на консолідованій основі (\% ВВП);

- заборгованість приватного сектору, обчислена на консолідованій основі (\% ВВП);

- загальний державний борг (\% ВВП);

- річна зміна боргових зобов'язань фінансового сектору на неконсолідованій основі (\%).

Наведені 7 показників є фінансовими, оскільки стосуються загального стану фінансових активів та пасивів, а саме: інвестицій, кредитів, боргових зобов'язань, національної валюти. Водночас, вони $\epsilon$ макроекономічними з огляду на те, що віддзеркалюють пропорції усієї національної економіки. Тому вони сконструйовані так, що передбачають подання та оцінювання на тлі таких макроекономічних змінних, як: досягнутий обсяг ВВП, загальний рівень цін, взаємодія інституційних секторів тощо.

Аналіз змін в оцінюванні дисбалансів - від Маастрихтських критеріїв 1992 [7] до Табло «MIP Scoreboard» 2011 р. та Табло «МIP Scoreboard» 2018 р. - дає підстави для важливих узагальнень щодо 
еволюції змісту поняття «макрофінансове». Зокрема, не можна не помітити факт зміщення акцентів у Табло від показників, переважно, 3 фінансовим змістом на користь показників, які характеризують стан реального сектору економіки. Така зміна є реакцією на події, пов'язані 3 фінансовою кризою 2008 - 2010 рр. та усвідомленням необгрунтованого переоцінювання ролі фінансового сектору в розвитку національних та світової економік. Показовим є те, що у Табло 2018 р. подано 4 нові показники, 3 яких 3 стосуються зайнятості активного населення, зайнятості молоді, тривалості безробіття. Отже, йдеться про переміщення акценту на трудовий потенціал реального сектору економіки.

Ми доходимо висновку, що в якості макрофінансових мають розглядатися процеси (явища), відповідно - набір показників, осердя яких складають ті, що стосуються руху фінансових активів/пасивів. Однак, цей перелік має охоплювати (імплементувати) й ті показники реальної економіки, які безпосередньо пов'язані 3 цим рухом та визначають його. Йдеться, до прикладу, про показники, серед яких:

- сукупні витрати загалом та чистий експорт зокрема;

- загальний рівень цін;

- співвідношення заробітної плати та загальної продуктивності;

- безробіття та зайнятість.

Важливим моментом у тлумаченні змісту поняття «макрофінансове» $\epsilon$ визнання того, що набір показників для оцінювання макрофінансових диспропорцій не може залишатися незмінним. Показовим, наприклад, $\epsilon$ те, що на початку 1990-х pр., у складі 4-х Маастрихтських критеріїв, один стосувався загального рівня цін, визначеного за темпом інфляції. У сучасних критеріях - Табло МIP - ідеться лише про індекс иін на житло. Причиною такої зміни акцентів, імовірно, є втрата для країн ЄС вже у 2010-х рр. актуальності проблеми надмірної інфляції. Натомість, на початку 1990-х рр. ця проблема була актуальною для них як така, що створювала загрози для макроекономічної стабільності. Попри все, загальний рівень цін, у який би спосіб він не відображався через різні форми оцінювання інфляції, через дефлювання номінальних показників на індекс цін тощо, $-\epsilon$ частиною явища «макрофінансове».

На наш погляд, для більш точної ідентифікації змісту поняття «інституційний дизайн макрофінансової безпеки» мають використовуватися показники з Табло МІР країн СС для оцінювання дисбалансів. Незаперечно, що в конкретних умовах окремих країн, зокрема в Україні, ці показники потребуватимуть певної модифікації з метою кращого пристосування. До прикладу, перманентні загрози небезпечних рівнів української інфляції спричинятимуть необхідність імплементації безпосередніх іï показників у особливе «Табло українських дисбалансів». Імовірно, що тим самим «специфічно українським» показником дисбалансів мав би бути показник рівня тінізації економіки, з огляду 
на фактичну неспівставно значну щодо інших країн світу частку тіньової економіки в структурі національної економіки.

Позитивна відповідь на питання про цінність досвіду країн ЄС для уточнення змісту поняття «макрофінансове» може грунтуватися на таких аргументах. По-перше, нагромаджена база даних щодо кількісних значень сконструйованих показників дає підстави для об'єктивного оцінювання переваг та обмежень підходу. По-друге, використовувані показники мають достатньо зрозумілий зміст, який може інтерпретуватися як макрофінансовий.

Для обгрунтування змін в інституційному дизайні макрофінансової безпеки важливим $\epsilon$ й аналіз досвіду країн поза межами ЄС. Насамперед для нас важливе українське застосування поняття «макрофінансове». 3 аналізу нормативно-правової бази передовсім випливають такі узагальнення.

По-перше, термін «макрофінансове» відсутній у законах України, але використовується органами державної влади в документах нижчого (ніж закони) рівня. Найбільш активним користувачем цього терміна виявляється Національний банк України (НБУ). В сучасних документах НБУ термін «макрофінансове» використовується у таких контекстах:

- «мінімізація загроз макрофінансової стабільності» [8];

- «посилення загроз для макрофінансової стабільності» [9];

- «забезпечення макрофінансової стабільності» [10].

Аналіз змісту згаданих документів НБУ дає підстави для висновку про таке загальне тлумачення «макрофінансової стабільності». Це те, що залежить від:

- постійності наповнення бюджету й пов'язаної з дефіцитом бюджету інфляції;

- виконання програм співпраці з МВФ;

- економічного зростання;

- узгодженості дій НБУ, Міністерства фінансів України та інших пов' язаних з ними інститутів.

У постановах іншого інституту - Верховної Ради України (ВРУ) термін «макрофінансове» використовується, зокрема, в таких контекстах:

- «умови для макрофінансової стабілізації» [11];

- додаткова макрофінансова допомога [12].

3 аналізу змісту згаданих документів (постанов ВРУ) виплаває тлумачення терміна «макрофінансове» як явища, що пов'язане 3 інвестиціями, переважно іноземними, та явища, що суттєво залежить від допомоги міжнародних фінансових організацій.

3 аналізу документів НБУ випливає й достатньо скептичне ставлення до можливості оцінювання стабільності. Зокрема, цей скепсис виявляється при згадуванні «макропруденційної політики, метою якої $€$ забезпечення фінансової стабільності» [13]. У публікації головного 
експерта Департаменту фінансової стабільності [14], розміщеної на сайті Експертної платформи - об’єднання співробітників НБУ констатується, що немає універсальних показників вимірювання й можна використовувати серію показників, об'єднаних в інтегральні індекси. Останні створюють можливість оцінювання поточного стану, але, як фіксує автор документа, не дають можливість передбачати.

Ми, натомість, вважаємо доцільним, 3 наукової та прикладної позицій, пошук саме в царині способів оцінювання макрофінансової безпеки, який би спирався на обгрунтоване тлумачення терміна «макрофінансове».

Більш конкретизоване тлумачення аналізованого нами терміна, 3 боку інститутів публічної влади - стейкхолдерів української економічної політики - на наш погляд, можна віднайти в офіційних методиках оцінювання. Такою, зокрема, $є$ чинна методика оцінювання рівня економічної безпеки, затверджена 2013 р. Міністерством економічного розвитку і торгівлі України [15].

Згадана методика не містить власне поняття «макрофінансове», але в ній подано розгорнуте й конкретизоване тлумачення «макроекономічного» та «фінансового». Стислий перелік показників подано в аналітичній табл. 2.

Таблиия 2

Показники для оцінювання макроекономічної та фінансової безпеки, за чинною в Україні офіційною методикою 2013 р.

\begin{tabular}{|c|c|}
\hline Показники & \begin{tabular}{|c|} 
Кількість \\
показників
\end{tabular} \\
\hline \multicolumn{2}{|l|}{ Макроекономічна безпека } \\
\hline Різниця між значеннями індексу продуктивності праці та заробітної & \\
\hline & 1 \\
\hline Рівень тінізації економіки (\% ВВП) & 1 \\
\hline Сальдо поточного рахунку платіжного балансу (\% ВВП) & 1 \\
\hline Рівень безробіття, за методологією МОП (\%) & 1 \\
\hline $\begin{array}{l}\text { Рівень тривалості безробіття - частка безробітних більше } 12 \\
\text { місяців (\%) }\end{array}$ & 1 \\
\hline $\begin{array}{l}\text { Різниця між темпом економічного зростання країни та відповідним } \\
\text { середнім показником для країн, що розвиваються (в. п.) }\end{array}$ & 1 \\
\hline Індекс споживчих цін (грудень до грудня) (разів) & 1 \\
\hline Наявний дохід населення у ВВП (\%) & 1 \\
\hline Схильність до заощаджень (\%) & 1 \\
\hline $\begin{array}{l}\text { Співвідношення між середньою зарплатою та всіма видами } \\
\text { допомоги і сочіальних трансфертів (разів) }\end{array}$ & 1 \\
\hline $\begin{array}{l}\text { Співвідношення між ВВП на душу населення в Україні та в } \\
\text { крайнах } С С(\%)\end{array}$ & 1 \\
\hline Зайнятість населення в неформальному секторі економіки (\%) & 1 \\
\hline Разом & 12 \\
\hline
\end{tabular}


Продовження табл. 2

\begin{tabular}{|l|c|}
\hline Фінансова безпека & 7 \\
\hline Група показників банківської безпеки & 4 \\
Група показників небанківського фінансового ринку & 5 \\
Група показників боргової безпеки & 4 \\
Група показників бюджетної безпеки & 6 \\
Група показників валютної безпеки & 6 \\
Група показників грошово-кредитної безпеки & $\mathbf{3 2}$ \\
\hline Разом & $\mathbf{4 4}$ \\
\hline Всього & \\
\hline
\end{tabular}

Джерело: розроблено авторами самостійно на основі офіційних методичних рекомендацій щзодо розрахунку рівня економічної безпеки України від 2013 р.

Подані в табл. 2 показники є своєрідним чинним «українським табло» для визначення рівня макроекономічної та фінансової безпеки, подібним до табло країн ЄС. Власне факт наявності переліку таких показників та достатньо зрозумілі алгоритми розрахунків, на наш погляд, $є$ значним здобутком української системи публічного управління. Компаративний аналіз «українського табло» на тлі табло країн ЄС дає підстави для таких узагальнень:

- частина показників, що ідентифіковані в українській методиці оцінювання як макроекономічні, мають, переважно, соціальноекономічне «навантаження», оскільки стосуються стану соціальної сфери. Вони віддзеркалюють не стільки власне макроекономічні пропорції, скільки пропорції у соціальній сфері. Це, зокрема, стосується показників: перерозподілу доходів через податки, внеску різних видів соціальної допомоги та трансфертів у сукупні доходи, порівняльного (відносного) добробуту громадян. Ідеться про такі показники з переліку показників української методики оцінювання (табл. 2), як: частка наявного (після оподаткування) доходу населення у ВВП; співвідношення між середньою зарплатою та всіма видами допомог і соціальних трансфертів; міра наближення ВВП на душу населення в Україні до показників СС (\%); частка зайнятого населення в неформальному секторі економіки;

- рівень деталізації показників фінансової сфери (їх кількість становить 32) може вважатися надмірним. Поділ фінансових показників на 6 груп передбачає розрахунок 6 субіндексів: банківської, небанківських фінансових посередників, боргової, бюджетної, валютної, грошовокредитної безпеки. Це значно ускладнює оцінювання цієї сфери та інтерпретацію результатів, а також прийняття на основі цієї інтерпретації управлінських рішень.

Попри зазначені особливості, так зване «українське табло» в його чинному тлумаченні, є достатньо прикладним. Тривале застосування 
впродовж багатьох років (методика 2013 р. спиралася на подібну методику 2007 р. [16]) створило значну інформаційну базу. Чинна методика, на наш погляд, придатна не лише для оцінювання поточного стану та обгрунтування поточних рішень, а й для передбачень та обгрунтування управлінських рішень для майбутнього.

Скористаймося для аналізу даними розрахунку, за «українським табло», інтегрального показника (індексу) національної економічної безпеки та двох показників (субіндексів) макроекономічної і фінансової безпеки (табл. 3).

Таблиия 3

Динаміка показників рівня безпеки, за українськими даними згідно з офіційною методикою 2013 р., за період 2007 - 2018 рр. (\%)

\begin{tabular}{|l|c|c|c|c|c|c|c|c|c|c|c|c|}
\hline $\begin{array}{c}\text { Показники } \\
\text { безпеки }\end{array}$ & $\mathbf{2 0 0 7}$ & $\mathbf{2 0 0 8}$ & $\mathbf{2 0 0 9}$ & $\mathbf{2 0 1 0}$ & $\mathbf{2 0 1 1}$ & $\mathbf{2 0 1 2}$ & $\mathbf{2 0 1 3}$ & $\mathbf{2 0 1 4}$ & $\mathbf{2 0 1 5}$ & $\mathbf{2 0 1 6}$ & $\mathbf{2 0 1 7}$ & $\mathbf{2 0 1 8}$ \\
\hline макроекономічної & 48 & 38 & 44 & 38 & 48 & 38 & 39 & 32 & 31 & 35 & 37 & 41 \\
\hline фінансової & 64 & 51 & 42 & 44 & 47 & 46 & 50 & 38 & 36 & 40 & 42 & 46 \\
\hline $\begin{array}{l}\text { загальної } \\
\text { економічної }\end{array}$ & 52 & 48 & 46 & 47 & 50 & 46 & 48 & 45 & 44 & 48 & 48 & 50 \\
\hline
\end{tabular}

Джерело: складено авторами на основі [17].

У таблиці репрезентовано показники рівня 3 безпек: загальної економічної та іiі складників - макроекономічної й фінансової. Показники рівня безпеки оцінено із застосуванням статистичного інструментарію інтегральних індексів за алгоритмом, визначеним у методиці, затвердженій Міністерством економічного розвитку та торгівлі у 2013 р.

У відповідності з загальними статистичними правилами побудови інтегральних індексів, у розрахунках використано процедури нормування показників та застосування вагових коєфіцієнтів. Фактично, йдеться про типову формулу для інтегральних індексів:

$$
I_{S}=\sum_{i=1}^{m} k_{m} n_{m},
$$

де $I_{S}$ - інтегральний індекс, у нашому випадку - індекс безпеки, який формується $3 m$ показників; $k_{m}$ - вагові коєфіцієнти змінних (показників), що використовуються для визначення індексу; $n_{m}$ - нормовані значення змінних (показників), що використовуються в розрахунках індексу.

Для кращої візуалізації дані табл. 3 подано нами на рис. 1, який, окрім фактичних значень показників (індексів) рівня безпеки, віддзеркалює ще й п'ять зон безпечності: критичну, небезпечну, незадовільну, задовільну, оптимальну зони. 


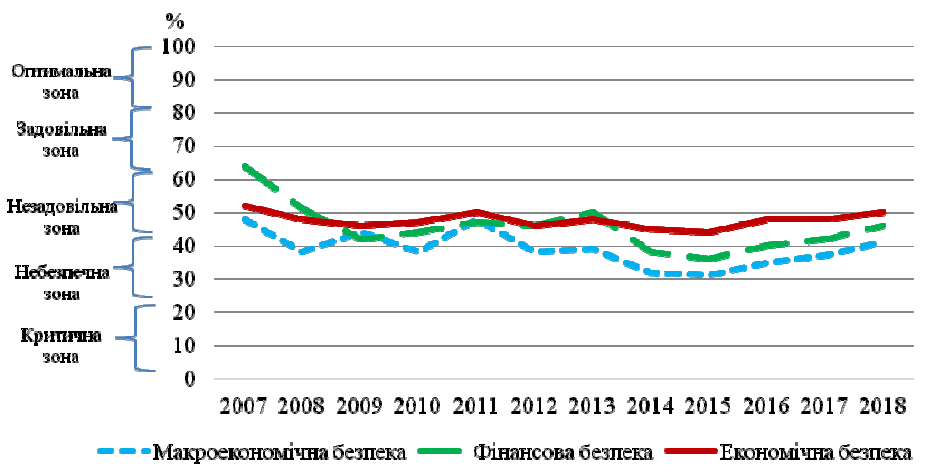

Рис. 1. Динаміка показників загальної економічної, макроекономічної та фінансової безпеки в межах зон безпечності у $2007-2018$ pp.

Джерело: створено самостійно на основі інформачиї з табл. 3.

Аналіз інформації, поданої на рис. 1, дає підстави для таких узагальнень:

- упродовж аналізованого періоду всі показники - загальної економічної, макроекономічної та фінансової безпеки - здебільшого перебували в зоні незадовільного стану. Виняток становить лише показник фінансової безпеки у 2007 р., що потрапляв у зону задовільного стану, та показники фінансової і макроекономічної безпеки, які в початковий період російсько-української війни 2014 2017 рр. перебували у зоні небезпечного стану;

- рівні макроекономічної та фінансової безпеки за всі 12 досліджуваних років були нижчими, ніж рівень загальної економічної безпеки, оцінюваної з використанням інтегрального індексу 3 ще 7 субіндексами, передбаченими методикою 2013 р., а саме: демографічної, соціальної, продовольчої, виробничої, енергетичної, зовнішньоекономічної та інвестиційно-інноваційної безпеки;

- рівень макроекономічної безпеки зазвичай був нижчим за рівень фінансової безпеки.

Якщо припускати, що інформація, подана на рис. 1, є об’ єктивною й релевантною, то 3 неї випливають принаймні такі передбачення (прогностичні висновки):

- показники рівня макроекономічної та фінансової безпеки мають бути більшою мірою в центрі уваги - моніторингу, аналізу, публічного обговорення, застосування інструментів впливу - національних регуляторів, ніж інші складники безпеки;

- за умов фактичного абсолютного спаду української економіки у 2019 - 2020 рр., показники макроекономічної та фінансової безпеки 
можуть зменшитися до рівня, який спостерігався у 2015 р. Саме у цей рік відбувався найглибший економічний спад у досліджуваному періоді.

Наш проміжний висновок щодо уточнення змісту поняття «макрофінансова стабільність (безпека)» для формування відповідного інституційного дизайну втілюється у такому тлумаченні поняття «макрофінансове». «Макрофінансове» - це поєднання макроекономічного (пов'язаного передовсім з рухом матеріальних активів) та фінансового (пов'язаного 3 національними фінансовими активами). Критерієм органічності такого поєднання є відповідність, за якої стан фінансової сфери не створює загроз для реального сектору економіки, а стан реального сектору - загроз для фінансової сфери.

Спираючись на досвід використання Табло країн ЄС та практику оцінювання економічної безпеки в Україні, ми припускаємо можливість створення оновленого «українського табло». Ймовірно, що саме навколо нього міг би формуватися український дизайн макрофінансової безпеки. Якщо виходити 3 доцільності визначення обмеженого кола 3 10-х показників, то вони, на наш погляд, могли би бути такими:

1. Річне сальдо рахунку поточних операцій платіжного балансу (у \% до ВВП).

2. Річна зміна реального обмінного курсу (в. п.).

3. Річний темп інфляції (\%).

4. Достатність офіційних валютних резервів (у місяцях імпорту).

5. Чиста міжнародна інвестиційна позиція (у \% до ВВП).

6. Державний борг (у \% до ВВП).

7. Відношення обсягу сукупних платежів з обслуговування та погашення державного боргу до доходів державного бюджету, відсотків (\%).

8. Рівень безробіття, за методологією МОП (\%).

9. Співвідношення між індексом продуктивності праці та індексом реальної заробітної плати (разів). ВВП).

10. Рівень тінізації економіки (частка тіньової економіки у \%

Пропонований перелік показників так званого «українського табло» $є$ скороченим порівняно 3 переліком, що охоплює десятки показників, передбаченим чинною українською методикою оцінювання макроекономічної та фінансової безпеки.

Перелік показників пропонованого «скороченого українського табло» для оцінювання рівня макрофінансової безпеки має такі особливості, спричинені особливостями поточного стану української економіки і суспільства: 
- містить 7 відносних показників стану національних фінансових активів та 3 показники (безробіття, співвідношення змін загальної продуктивності праці й зарплати, частки тіньової економіки), які характеризують стан реального сектору. Значна частка від загальної кількості показників (30\%), що безпосередньо стосуються стану реального сектору, може пояснюватися перманентним і тривалим перебуванням української економіки в спадній частині реального економічного циклу. Відтак, зростає вага таких показників, як зайнятість ресурсів, продуктивність, частка економіки в тіні;

- передбачає використання річних (а не середніх за певний період, як у Табло (С) показників, з огляду на значну економічну волатильність, відсутність достатньо тривалих періодів стабільної динаміки. Відтак, об'єктивно необхідним стає моніторинг і контроль короткотермінових (річних) змін;

- складається з обмеженого кола показників для спрощення процедури ідентифікації функцій та розподілу повноважень між органами публічної влади у межах інституційного дизайну. Адже формування дизайну публічного управління об' єктивно ускладняється за більшого переліку показників.

У контексті досліджуваної нами проблеми після окреслення того, навколо яких процесів, явищ, відповідно, показників має формуватися інституційний дизайн, важливо уточнити власне зміст поняття інституційного дизайну. Сучасна політична наука пропонує багато підходів до його тлумачення. Зупинимося лише на декількох, а саме тих, які, на наш погляд, можуть мати найбільше практичне застосування.

У книзі Robert E. Goodin, присвяченій теорії інституційного дизайну [18], останній потрактовано як дієву форму просування ціннісних результатів у конкретному контексті. Практичність цього акценту у визначенні змісту інституційного дизайну, на наш погляд, пов'язана з визнанням важливості усвідомлення об'єктивних цінностей суспільства та творення ефективної форми їх реалізації.

Josep M. Colomer [19] визначає інституційний дизайн як «вибір правил для прийняття колективних рішень». Акцентується на тому, що інститути можуть створювати обмеження для колективних рішень i тому зменшують невизначеність. Натомість, дизайн, за авторським уявленням, покликаний створювати гармонійне середовище для взаємодії у суспільстві.

У книзі David L. Weimer [20], присвяченій інституційному дизайну, 3 огляду на проблеми реалізації державної політики, інституційний дизайн визначається як відносно стійкий набір взаємопов'язаних правил та стимулів, що формують узгоджені процедури, призначені для досягнення предметних цілей. 
Серед визначень інституційного дизайну, пропонованих українськими дослідниками, важливими для нашого дослідження $€$ принаймні такі:

- «цілеспрямоване компонування інститутів з метою упорядкування правил, що регулюють взаємовідносини між людьми у передбачуваному напрямку з метою відповідності існуючим потребам і змінам» [21];

- «динамічний процес трансформаційних змін існуючих традиційних інститутів у стан нових» [22].

Практична цінність двох останніх визначень від українських дослідників пояснюється акцентуванням на необхідності зміни форм та правил остільки, оскільки змінюються потреби користувачів дизайну. Фактично, йдеться про динамічний підхід до визначення змісту інституційного дизайну.

Чинне законодавство України не містить визначення терміна «дизайн» ні у загальному сенсі, ні в сенсі дизайну для національної макрофінансової безпеки. Але в ньому використовується поняття «дизайну продукту». Це - «сукупність процесів, які перетворюють правові, технічні, функціональні, ринкові вимоги, вимоги щодо безпеки чи інші вимоги, яким повинен відповідати продукт, у технічну специфікацію на такий продукт» [23]. Практична спрямованість цього визначення полягає у тому, що ним визнається необхідність відповідності між дизайном та об'єктивними вимогами, включно з безпековими, та те, що дизайн передбачає певні нормативи (специфікації).

3 огляду на все зазначене, надалі в якості робочої гіпотези ми користуватимемося таким визначенням: «Інституційний дизайн $\epsilon$ формою реалізачіі спроєктованих процедур, алгоритмів взаємодії, правил, стимулів та обмежень, які забезпечують иіннісні орієнтири суспільства (громад) у певних сферах». Зрозуміло, що інституційний дизайн у публічній сфері, якою і є сфера національної економічної безпеки, має спиратися на інститути влади, у взаєминах між якими та між якими й суспільством існує унормований розподіл повноважень та відповідальності.

Узагальнення щодо доцільності або, навпаки, недоцільності певного інституційного дизайну макрофінансової безпеки можуть на даний час спиратися на аналіз діяльності інститутів ЄС. Ідеться передусім про вже згадувану нами процедуру макроекономічних дисбалансів (The Macroeconomic Imbalance Procedure - MIP) та пов' язані з нею документи і практики регулювання [23-32].

Основні взаємини у формуванні інституційного дизайну макрофінансової безпеки, за нормативними документами СС, складаються між такими інститутами цього утворення:

- Свропейська Комісія (European Commssion);

- Свропейська Рада (European Council); 
- Рада СC (Council of the EU (Council));

- країни-учасниці (Member States);

- Свропейський Парламент (European Parliament).

Інституційний дизайн макрофінансової безпеки ЄС є достатньо складним. Гранично спрощено він поданий нами у вигляді так званої «матриці взаємодії інститутів ЄС». Причому йдеться про два етапи загальної процедури, а саме виявлення дисбалансів та реагування (дії після діагностування надмірних дисбалансів). Ці два етапи, відповідно, дві матриці взаємодії репрезентовано у табл. 4 та табл. 5.

Таблиия 4

\section{Матриця спеціальних функцій інститутів СС щодо виявлення макрофінансових дисбалансів}

\begin{tabular}{|c|c|c|c|c|}
\hline $\begin{array}{l}\text { Свропейська Комісія } \\
\text { (European Commssion) }\end{array}$ & $\begin{array}{c}\text { Європейська } \\
\text { Рада } \\
\text { (European } \\
\text { Council) }\end{array}$ & $\begin{array}{c}\text { Рада } \mathrm{EC} \\
\text { (Council of the } \\
\text { EU (Council)) }\end{array}$ & $\begin{array}{c}\text { Крани-члени СС } \\
\text { (Member States) }\end{array}$ & $\begin{array}{c}\text { Свропейський } \\
\text { Парламент } \\
\text { (European } \\
\text { Parliament) }\end{array}$ \\
\hline 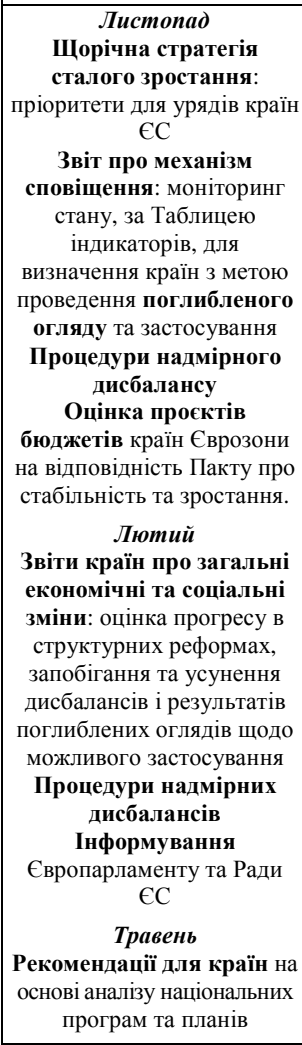 & $\begin{array}{c}\text { Листопад } \\
\text { Організація } \\
\text { дискусії щодо } \\
\text { Щорічної } \\
\text { стратегії сталого } \\
\text { зростання та } \\
\text { Звіту про } \\
\text { механізм } \\
\text { оповіщення для } \\
\text { координації } \\
\text { економічних } \\
\text { політик країн } \\
\text { ЄС } \\
\text { Березень } \\
\text { Вказівки щодо } \\
\text { пріоритетів } \\
\text { національних } \\
\text { реформ у } \\
\text { програмах та } \\
\text { бюджетних } \\
\text { планах. } \\
\text { Червень-липень } \\
\text { Затвердження } \\
\text { остаточних } \\
\text { Рекомендацій } \\
\text { для кожної } \\
\text { країни }\end{array}$ & \begin{tabular}{|c|} 
Листопад \\
Участь у \\
дискусії про \\
Щорічну \\
стратегію \\
сталого \\
зростання \\
Обговорення \\
оцінки \\
Єврокомісії \\
щодо проєктів \\
бюджетів країн \\
Єврозони \\
Грудень-січень \\
Схвалює \\
Рекомендації \\
для Єврозони \\
на основі \\
листопадових \\
обговорень \\
документів \\
ЄС, Щорічну \\
стратегію \\
сталого \\
розвитку та \\
Звіт про \\
механізм \\
оповіщення \\
Червень- \\
липень Участь \\
в обговоренні \\
впровадження \\
Рекомендацій \\
для Єврозони в \\
окремих \\
країнах ЄС
\end{tabular} & $\begin{array}{c}\text { Жовтень } \\
\text { Проєкти } \\
\text { бюджетів на } \\
\text { наступний рік } \\
\text { Участь у } \\
\text { двосторонніх } \\
\text { перемовинах } 3 \\
\text { Єврокомісією } 3 \\
\text { бюджетних питань } \\
\text { та пріоритетів } \\
\text { розвитку } \\
\text { Грудень } \\
\text { Ухвалення } \\
\text { бюджетних планів } \\
\text { Квітень } \\
\text { Національні } \\
\text { програми реформ } \\
\text { та стабільності / } \\
\text { конвергенцї, з } \\
\text { визначенням } \\
\text { шляхів } \\
\text { запобігання / } \\
\text { виправлення } \\
\text { дисбалансів, } \\
\text { дотримання } \\
\text { фіскальних правил } \\
\text { та пріоритетів } \\
\text { розвитку } \\
\text { Серпень-вересень } \\
\text { Імплементація } \\
\text { визнаних } \\
\text { інститутами ЄС } \\
\text { Рекомендацій у } \\
\text { національне } \\
\text { законодавство та } \\
\text { щорічні бюджети }\end{array}$ & $\begin{array}{c}\text { Листопад } \\
\text { Організація } \\
\text { дискусії щодо } \\
\text { пріоритетів, } \\
\text { окреслених у } \\
\text { Щорічній } \\
\text { стратегї̈ } \\
\text { сталого } \\
\text { зростання } \\
\text { Участь в } \\
\text { обговоренні } \\
\text { Звіту про } \\
\text { механізм } \\
\text { сповіщення } \\
\text { Лютий } \\
\text { Приймає } \\
\text { Щорічну } \\
\text { стратегію } \\
\text { сталого } \\
\text { розвитку та Звіт } \\
\text { про механізм } \\
\text { оповіщення } \\
\text { Травень } \\
\text { Дискусія щодо } \\
\text { опублікованих } \\
\text { Єврокомісією } \\
\text { Рекомендацій } \\
\text { для країн- } \\
\text { членів ЄС }\end{array}$ \\
\hline
\end{tabular}

Джерело: створено авторами самостійно. 
Реалізація функцій інститутів СС, репрезентованих в аналітичній табл. 4, завершується встановленням факту надмірних дисбалансів. Подальші дії інститутів спрямовані безпосередньо на коригування ситуації (табл. 5).

Табличя 5

Матриця спеціальних функцій інститутів ЄС, які реалізуються після виявлення надмірних макрофінансових дисбалансів

\begin{tabular}{|c|c|c|c|c|}
\hline $\begin{array}{l}\text { Свропейська } \\
\text { Комісія } \\
\text { (European } \\
\text { Commssion) }\end{array}$ & $\begin{array}{c}\text { Європейська } \\
\text { Рада } \\
\text { (European } \\
\text { Council) }\end{array}$ & $\begin{array}{c}\text { Рада } \mathrm{EC} \mathrm{(Council} \\
\text { of the EU } \\
\text { (Council)) }\end{array}$ & $\begin{array}{c}\text { Крани-члени СС } \\
\text { (Member States) }\end{array}$ & $\begin{array}{c}\text { Європейський } \\
\text { Парламент } \\
\text { (European } \\
\text { Parliament) }\end{array}$ \\
\hline $\begin{array}{c}\text { Червень } \\
\text { Рішення про } \\
\text { початок } \\
\text { Процедури } \\
\text { обмеження } \\
\text { надмірних } \\
\text { дисбалансів, } \\
\text { інформування } \\
\text { інших } \\
\text { інститутів ЄС } \\
\text { про системні } \\
\text { ризики та } \\
\text { Звіт про } \\
\text { прийнятність } \\
\text { Плану дій } \\
\text { Рекомендації } \\
\text { щодо } \\
\text { застосування } \\
\text { санкцій, їх } \\
\text { планової або } \\
\text { дострокової } \\
\text { відміни }\end{array}$ & & $\begin{array}{c}\text { Червень } \\
\text { Рекомендації } \\
\text { країнам щодо } \\
\text { заходів для } \\
\text { Плану } \\
\text { коригуючих дій } \\
\text { Рекомендації } 3 \\
\text { усунення } \\
\text { надмірних } \\
\text { дисбалансів у разі } \\
\text { прийнятності } \\
\text { Плану та } \\
\text { Рекомендації } \\
\text { щодо змін Плану } \\
\text { коригувальних } \\
\text { дій, за } \\
\text { висновками } \\
\text { наглядових місій } \\
\text { Рішення про } \\
\text { застосування } \\
\text { санкцій до країн } \\
\text { та про їх відміну }\end{array}$ & $\begin{array}{c}\text { Червень } \\
\text { Розробка Планів } \\
\text { конкретних дії з } \\
\text { термінами } \\
\text { виконання та їх } \\
\text { подання для аналізу } \\
\text { Єврокомісії } \\
\text { Розробка } \\
\text { оновлених Планів } \\
\text { коригуючих дій (за } \\
\text { потреби) } \\
\text { Виконання } \\
\text { санкцій у разі } \\
\text { визнання Радою } \\
\text { неприйнятності } \\
\text { Планів або їх } \\
\text { недотримання } \\
\text { країною Єврозони. } \\
\text { Звітування перед } \\
\text { Єврокомісією та } \\
\text { Радою про прогрес } \\
\text { у подоланні } \\
\text { дисбалансів }\end{array}$ & \\
\hline
\end{tabular}

Джерело: створено авторами самостійно.

3 аналізу інформації, поданої у таблицях, можна зробити такі узагальнення щодо змісту інституційного дизайну макрофінансової безпеки $\mathrm{CC}$ :

1. Інструментами впливу на ситуацію з боку основних інститутів $€ \mathrm{C}$, через які підтримується макрофінансова стабільність (безпека), можуть ставати:

- загальна стратегія розвитку з окресленням пріоритетів;

- загальні правила, репрезентовані передусім певними макрофінансовими показниками;

- перманентний моніторинг подій та оцінювання ризиків;

- публічне обговорення результатів моніторингу; 
- аналіз національних програм та результатів розвитку країн для визначення відхилень (дисбалансів);

- офіційні рекомендації щодо планів коригуючих дій з обмеження дисбалансів, виявлених у процесі моніторингу;

- звіти за результатами виконання затверджених планів коригуючих дій;

- визначення, застосування та відміна санкцій щодо країнпорушниць встановлених правил.

2. Інституційний дизайн передбачає чітко розподілені повноваження та відповідальність інститутів влади. Інститути залучаються до окремих етапів процедури обмеження дисбалансів, лише виходячи з призначення (цілей, повноважень) кожного з них. Тому, два 3 п'ятьох інститутів СС Європейська Рада (European Council) та Європейський Парламент (European Parliament) - не беруть безпосередньої участі в реалізації завершального етапу застосування санкцій для усунення дисбалансів.

3. Застосування інструментів регулювання дисбалансів чітко фіксоване та узгоджене у часі впродовж кожного року. Відтак, дотримання часових меж постає важливим правилом регулювання дисбалансів.

Для обгрунтування пропозицій щодо формування інституційного дизайну макрофінансової безпеки в Україні, зокрема в частині застосування досвіду ЄС, необхідно об'єктивно оцінити існуючий дизайн. Ідеться передусім про фіксацію надбань та проблем в організації системи публічного управління станом безпеки.

До основних надбань у формуванні українського інституційного дизайну, на наш погляд, належить таке:

- існування офіційних методик оцінювання рівня економічної безпеки, розроблених за ініціативи Міністерства економічного розвитку України у 2007 р. та у 2013 р., та доступність джерел первинної інформації для розрахунків і офіційних результатів розрахунків;

- створення проєктів двох Указів Президента України 2015 р. та 2018 р., у яких закладалося підгрунтя для більш чіткого окреслення змісту діяльності владних інститутів, розмежування їх функцій та відповідальності щодо формування інформаційної бази, моніторингу, публікування результатів і планів заходів [33].

До основних недоліків (обмежень) у формуванні українського інституційного дизайну макрофінансової безпеки, на наш погляд, належить таке:

- відсутність запобіжників щодо припинення оприлюднення результатів розрахунків показників рівнів економічної безпеки у вільному доступі й перехід до обмеженої доступності інформації у формі офіційних запитів до відповідного міністерства; 
- ускладнення власних розрахунків, за офіційною методикою, через частковий брак офіційної інформації;

- дискретність (непослідовність) процесів формування дизайну, зокрема, через незатвердження проєктів двох згаданих (2015 та 2018 років) Указів Президента України, які спрямовували на створення основи унормування взаємодії органів державної влади в гарантуванні економічної (макрофінансової) безпеки.

Окремі фрагменти потенційного інституційного дизайну макрофінансової безпеки можемо віднайти в законодавстві щодо діяльності окремих інститутів української влади. Вони навряд чи можуть бути потрактовані власне як елементи сформованого дизайну макрофінансової безпеки через те, що вмонтовані в інші алгоритми. Зокрема, йдеться про алгоритм прийняття щорічного державного бюджету або алгоритм контролю за борговими показниками. Деякі фрагменти, які можуть скласти основу майбутнього інституційного дизайну макрофінансової безпеки, подано в Матриці спеціальних функцій (табл. 6).

Таблиия 6

Матриця спеціальних функцій інститутів української публічної влади, потенційно дотичних до макрофінансової безпеки

\begin{tabular}{|c|c|}
\hline $\begin{array}{l}\text { Інститути публічної } \\
\text { влади України }\end{array}$ & $\begin{array}{c}\text { Функції, дотичні до регулювання макрофінансових } \\
\text { дисбалансів }\end{array}$ \\
\hline $\begin{array}{l}\text { Верховна Рада } \\
\text { України (включно } 3 \\
\text { профільними } \\
\text { комітетами) (ВРУ) }\end{array}$ & $\begin{array}{l}\text { 1. Бере участь у підготовці пропозицій до щорічного } \\
\text { бюджетного плану. } \\
\text { 2. До 01.12.: ухвалює бюджет на наступний рік. } \\
\text { 3. До 15.07.: розглядає Бюджетну Декларацію. } \\
\text { 4. Ухвалює зміни впродовж року до бюджету. }\end{array}$ \\
\hline $\begin{array}{l}\text { Кабінет Міністрів } \\
\text { України (КМУ) }\end{array}$ & $\begin{array}{l}\text { 1. До 15.09.: схвалює проєкт державного бюджету та } \\
\text { подання його ВРУ та Президенту } 3 \text { урахуванням } \\
\text { лімітних вимог Бюджетного Кодексу. } \\
\text { 2. До 01.06.: схвалює Бюджетну Декларацію (прогнози } \\
\text { місцевих бюджетів). } \\
\text { 3. Затверджує Середньорічну стратегію управління } \\
\text { державним боргом. }\end{array}$ \\
\hline Президент України & $\begin{array}{l}\text { До 15.12.: може подати пропозиції до схваленого } \\
\text { проєкту бюджету. }\end{array}$ \\
\hline $\begin{array}{l}\text { Міністерство } \\
\text { фiнансів України } \\
\text { (Мінфін) }\end{array}$ & $\begin{array}{l}\text { 1. Складає проєкт державного бюджету та вносить } \\
\text { пропозиції щодо термінів і порядку його розгляду. } \\
\text { 2. До } 15.05 .: \text { подає на розгляд КМУ Бюджетну декларацію } \\
\text { (прогноз місцевих бюджетів) на наступні два періоди. } \\
\text { 3. Розробляє Середньорічну стратегію управління } \\
\text { державним боргом. } \\
\text { 4. Здійснює моніторинг та аналіз реалізації стратегії, } \\
\text { визначає пріоритети. }\end{array}$ \\
\hline
\end{tabular}


Продовження табл. 6

\begin{tabular}{|c|c|}
\hline & $\begin{array}{l}\text { 5. Формулює рекомендації (без термінів, конкретизації } \\
\text { виконавців). }\end{array}$ \\
\hline $\begin{array}{l}\text { Боргове агентство } \\
\text { України }\end{array}$ & $\begin{array}{l}\text { Реалізує політику в сфері управління } \text { боргом } 3 \\
\text { урахуванням середньострокової стратегії управління } \\
\text { державним боргом та умов дотримання граничного } \\
\text { обсягу державного боргу на кінець бюджетного періоду. }\end{array}$ \\
\hline $\begin{array}{l}\text { Національний банк } \\
\text { України (НБУ) }\end{array}$ & $\begin{array}{l}\text { 1. До 01.03: розробляє та подає макроекономічний } \\
\text { прогноз до Мінфіну для узгодження бюджетної політики. } \\
\text { 2. У межах своїх повноважень здійснює аналіз стану } \\
\text { фінансової системи. } \\
\text { 3. Розробляє та публікує щорічний Звіт про фінансову } \\
\text { стабільність. }\end{array}$ \\
\hline $\begin{array}{l}\text { Рада національної } \\
\text { безпеки та оборони } \\
\text { України (РНБО) }\end{array}$ & $\begin{array}{l}\text { 1. До 15.04.: на підставі обсягу видатків та надання } \\
\text { кредитів на національну безпеку і оборону на } \\
\text { середньостроковий період готує та надає Мінфіну } \\
\text { обгрунтовані пропозиції щодо іх розподілу між } \\
\text { головними розпорядниками коштів державного бюджету. } \\
\text { 2. Готує пропозиції до проєкту Закону про Державний } \\
\text { бюджет України до його схвалення КМУ за статтями, } \\
\text { пов'язаними із забезпеченням національної безпеки і } \\
\text { оборони України (з вмотивованим обгрунтуванням). }\end{array}$ \\
\hline \begin{tabular}{l|} 
Міністерство \\
економічного \\
розвитку України \\
(Мінекономрозвитку)
\end{tabular} & $\begin{array}{l}\text { 1. До 01.03: розробляє та подає макроекономічний } \\
\text { прогноз до Мінфіну для узгодження бюджетної політики } \\
\text { на наступні періоди. } \\
\text { 2. Розробляє механізм забезпечення економічної безпеки } \\
\text { держави. Двічі на рік здійснює розрахунок рівня } \\
\text { економічної безпеки, але не публікує його у вільному } \\
\text { доступі. }\end{array}$ \\
\hline $\begin{array}{l}\text { Рада з фінансової } \\
\text { стабільності України }\end{array}$ & $\begin{array}{l}\text { Виявляє загрози для фінансової стабільності та розробляє } \\
\text { рекомендації. }\end{array}$ \\
\hline $\begin{array}{l}\text { Міністерство } \\
\text { соціальної політики } \\
\text { України } \\
\text { (Мінсоцполітики) }\end{array}$ & $\begin{array}{l}\text { До 01.03.: Розробляє та подає прогноз соціальних } \\
\text { показників до Мінфіну для узгодження бюджетної } \\
\text { політики на наступні періоди. }\end{array}$ \\
\hline
\end{tabular}

Джерело: складено авторами самостійно на основі [34].

3 аналізу інформації, репрезентованої у формі аналітичної табл. 6, можна зробити висновок про брак часової та змістової узгодженості дій між окремими інститутами публічної влади. Це власне й дає підстави для висновку про відсутність цілісності у формуванні дизайну економічної безпеки. Так само не йдеться про цілісність інституційного дизайну макрофінансової безпеки, або безпеки, сформованої навколо так званого «українського табло».

3 огляду на все зазначене 3 приводу змісту поняття (явища) «макрофінансова безпека», табло показників для іiї оцінювання, а 
також зазначене 3 приводу інституційного дизайну загалом та його чинного українського втілення, доходимо висновку про обгрунтованість такого підходу до українського інституційного дизайну (рис. 1).

\begin{tabular}{|c|c|c|c|}
\hline $\begin{array}{c}\text { Зміст: «українське } \\
\text { табло» }\end{array}$ & Інститути & \multicolumn{2}{|c|}{$\begin{array}{c}\text { Процедури: інструменти, } \\
\text { терміни }\end{array}$} \\
\hline $\begin{array}{l}\text { 1. Річне сальдо рахунку } \\
\text { поточних операцій } \\
\text { платіжного балансу (у \% до } \\
\text { ВВП) } \\
\text { 2. Річна зміна реального } \\
\text { обмінного курсу (в.п.) } \\
\text { 3.Річний темп інфляції (\%) } \\
\text { 4. Достатність офіційних } \\
\text { валютних резервів (у } \\
\text { місяцях імпорту) } \\
\text { 5. Чиста міжнародна } \\
\text { інвестиційна позиція (у \% } \\
\text { до ВВП) } \\
\text { 6. Державний борг (у \% до } \\
\text { ВВП) } \\
\text { 7. Відношення обсягу } \\
\text { сукупних платежів } 3 \\
\text { обслуговування та } \\
\text { погашення державного } \\
\text { боргу до доходів } \\
\text { державного бюджету, } \\
\text { відсотків (\%) } \\
\text { 8. Рівень безробіття, за } \\
\text { методологією МОП (\%) } \\
\text { 9. Співвідношення між } \\
\text { індексом продуктивності та } \\
\text { індексом реальної зарплати } \\
\text { (разів) } \\
\text { 10. Рівень тінізації } \\
\text { економіки (частка тіньової } \\
\text { економіки у \% ВВП) }\end{array}$ & $\begin{array}{c}\text { Мінфін (та } \\
\text { пов'язані } \\
\text { інституції) }\end{array}$ & $\begin{array}{c}\text { Загальні стратегї } \\
\text { розвитку } \\
\text { (пріоритети) } \\
\text { Моніторинг і } \\
\text { звіти про } \\
\text { макрофінансову } \\
\text { стабільність та її } \\
\text { складники } \\
\text { впродовж року } \\
\text { Поглиблений } \\
\text { аналіз } \\
\text { найбільших } \\
\text { дисбалансів } \\
\text { Прогнози щодо } \\
\text { макрофінансових } \\
\text { дисбалансів } \\
\text { Плани } \\
\text { коригуючих дій } \\
\text { Сповіщення про } \\
\text { санкції та їх } \\
\text { відміну } \\
\text { Формування } \\
\text { комунікації зі } \\
\text { «стейкхолдерами» } \\
\text { політики з } \\
\text { приводу } \\
\text { дисбалансів: } \\
\text { оприлюднення, } \\
\text { пояснення причин } \\
\text { тощо }\end{array}$ & $\begin{array}{c}\text { Конкретні } \\
\text { дати, за } \\
\text { об'єктивною } \\
\text { логікою } \\
\text { процедур та } \\
\text { згідно з } \\
\text { Податковим } \\
\text { та } \\
\text { Бюджетним } \\
\text { кодексами, } \\
\text { іншими } \\
\text { законами } \\
\text { України }\end{array}$ \\
\hline
\end{tabular}

Рис. 1. Основи українського інституційного дизайну макрофінансової безпеки

Джерело: створено авторами самостійно.

На рис. 1 презентовано такі ідеї щодо формування основ цілісного дизайну макрофінансової безпеки української економіки:

- ключовими складниками інституційного дизайну є три елементи: зміст діяльності (параметри економіки, відповідно, показники, через які виявляється макрофінансова стабільність і безпека), інститути (органи публічної влади, діяльність та взаємодія яких забезпечує макрофінансову стабільність), процедури (інструменти й терміни, 3 використанням яких інститути забезпечують макрофінансову стабільність); 
- основний зміст інституційного дизайну має формувати обмежене коло показників, яке, у нашому випадку, пропонується в складі 10-х позицій. Цей перелік охоплює більшість показників, якими користуються країни $\mathrm{CC}$, але містить й особливі показники, які віддзеркалюють особливості української економіки (9-та та 10-та позиції). Не виключено, що коло з 10-х показників може розширюватися за рахунок додаткових конкретизованих за сферами вимірників макрофінансової стабільності та безпеки;

- осердя дизайну макрофінансової безпеки формується навколо діяльності та взаємодії трьох інститутів публічної влади - НБУ, Мінфіну і Мінекономіки. Це випливає з природних функцій цих інститутів з огляду на сфери, щодо яких вони виступають національними регуляторами. За змістом діяльності трьох згаданих інститутів, віддзеркаленим у чинній нормативній базі та існуючій практиці, вони об’єктивно пов'язані $з$ конкретними показниками «українського табло». Відповідно, зміст діяльності з управління балансами (дисбалансами) мав би розподілятися у такий спосіб: НБУ - 1-й, 2-й, 3-й, 4-й, 5-й показники, Міністерство фінансів України - 5-й, 6-й, 7-й показники, Міністерство економіки України - 8-й - 9-й, 10-й показники. Ймовірною $є$ «перехресна» відповідальність, або співвідповідальність НБУ та Мінфіну щодо показника «Чиста міжнародна інвестиційна позиція (у \% до ВВП). Якщо таке припущення $є$ обгрунтованим, то це б передбачало формулювання додаткових вимог з розмежування відповідальності, відтак - $з$ узгодження процедур;

- в якості «пов'язаних» 3 основними інститутами, які в цьому інституційному дизайні $\epsilon,-$ НБУ, Міністерством фінансів України та Міністерством економіки України - можуть діяти державні агенції, комітети, спеціальні комісії (центри взаємодії) тощо. Ймовірно, що до «пов'язаних інституцій» можуть належати або нині діючі, або новостворені 3 новими повноваженнями, підпорядкуванням, компетенціями тощо;

- формування релевантного інституційного дизайну макрофінансової безпеки могло б охоплювати такі випробувані в практиці публічного управління інструменти: стратегії з відповідними пріоритетами розвитку всієї економіки та іï окремих сфер, звіти за показниками табло, поглиблений аналіз дисбалансів при найбільших відхиленнях від нормативних значень показників, короткострокові прогнози дисбалансів, плани коригуючих дій, сповіщення про санкції, налагодження комунікації зі стейкхолдерами та бенефіціарами (вигодоотримувачами) урядової монетарної фінансової, інноваційної, зайнятості тощо політик;

- терміни щодо застосування інструментів окремими інститутами потребують глибшого аналізу, з огляду на чинні нормативно-правові документи, для обгрунтування необхідних змін, а також для обгрунтування алгоритмів взаємодії цих інститутів; 
- суб'єктами, до яких мали б застосовуватися інструменти інституційного дизайну - звіти, аналіз діяльності, прогнози результатів, сповіщення про санкції тощо, - на наш погляд, мали би бути не лише безпосередні суб'єкти економічної (макрофінансової сфери), місцеві органи влади, а й власне інститути публічного управління в особі конкретних керівників, підрозділів пов'язаних владних інститутів тощо.

Як результати дослідження визначеної наукової проблеми згідно 3 окресленою метою, можуть бути подані такі висновки:

- найбільшою мірою завданню формування інституційного дизайну макрофінансової безпеки відповідає таке тлумачення змісту поняття «макрофінансова сфера»: «Це - сегмент національної економіки, в межах якого здійснюється взаємопов'язаність (узгодженість) руху фінансових та реальних активів»;

- макрофінансова стабільність (безпека) національної економіки може репрезентуватися фактичними значеннями доцільного (обгрунтованого) кола показників, використання яких сприяє виявленню диспропорцій у взаєминах фінансового та реального секторів, що можуть загрожувати цілісності національної економіки. Коло цих показників й алгоритми їх розрахунків можуть частково змінюватися у зв'язку 3 новими економічними обставинами та викликами, які постають перед суспільством та національними регуляторами;

- наразі, доцільним виглядає використання 10-х показників для оцінювання макрофінансової стабільності (безпеки) у складі: річного сальдо рахунку поточних операцій платіжного балансу, річної зміни реального обмінного курсу, річного темпу інфляції, показника достатності офіційних валютних резервів, частки державного боргу у ВВП, чистої міжнародної інвестиційної позиції, дефіциту державного бюджету, рівня безробіття, співвідношення між індексом продуктивності праці та індексом реальної заробітної плати;

- найбільш прийнятним для формування інституційного дизайну є таке тлумачення його змісту: «Це - система спроєктованих алгоритмів, правил, стимулів та обмежень, які забезпечують ціннісні орієнтири суспільства (громад) у певних сферах»;

- основними елементами інституційного дизайну макрофінансової безпеки можуть вважатися: 1) власне показники для оцінювання макрофінансової безпеки, 2) інститути публічної влади, 3) процедури інструменти та терміни, - 3 використанням яких забезпечується виявлення та коригування надмірних дисбалансів;

- об'єктивно причетними до регулювання макрофінансової сфери, з огляду на іiі зміст, є три основні національні регулятори НБУ, Мінфін та Мінекономрозвитку України, а також пов’язані з ними 
інституції публічної влади. Основними інструментами формування макрофінансової безпеки в межах створеного інституційного дизайну мають бути: стратегії розвитку, моніторинг та оцінювання, загальні й спеціальні звіти, прогнози дисбалансів, плани коригуючих дій, сповіщення про застосування та відміну санкцій, формування комунікацій між національними регуляторами і суспільством (громадами) 3 приводу надмірних дисбалансів;

- подальші дослідження в царині формування інституційного дизайну макрофінансової стабільності (безпеки) мали би здійснюватися за такими напрямками: вдосконалення способів (методик) оцінювання макрофінансових дисбалансів, контент-аналізу нормативно-правових документів на предмет урегульованості функцій, інструментів, термінів, розподілу повноважень та відповідальності між інститутами влади, якісного й кількісного аналізу ефективності існуючої системи публічного управління за результатами забезпечення макрофінансової стабільності, проєктування необхідних змін у всіх елементах інституційного дизайну.

\section{Jimepamypa:}

1. Comunale M. A panel VAR analysis of macro-financial imbalances in the EU: ECB Working Paper. 2017. №2026. URL : https://www.econstor.eu/ bitstream/10419/162689/1/88485681X.pdf.

2. Lanehttps $\mathrm{Ph}$. Macro-financial stability under EMU: Working Paper Series. February 2016. №1. URL : www.esrb.europa.eu/pub/pdf/wp/ esrbwp1.en.pdf.

3. Dewachter H., Iania L., Lemke W., Lyrio M. A macro-financial analysis of the corporate bond market. European Central Bank (ECB). Working Paper Series. 2018. №2214. URL : https://www.ssrn.com/abstract $=3299971$.

4. Benigno G., Chen H., Otrok Ch., Rebucci A., Young E. Optimal Policy for Macro-Financial Stability: Working Paper 2012-041. St. Louis Fed Publications. URL : https://doi.org/10.20955/wp.2012.041.

5. European Commission, Commission staff working paper scoreboard for the surveillance of macroeconomic imbalances: envisaged initial design. 2011. URL : http://www.europarl.europa.eu/sides/getDoc.do? pubRef=-//EP//TEXT+TA+P7-TA-2011-0583+0+DOC+XML+V0//EN.

6. European Commission, Technical note envisaged revision of selected auxiliary indicators of the MIP scoreboard. 2018. URL : https://ec.europa.eu/info/sites/info/files/economy-finance/technical_note_ proposal_mip_aux_indicators_revision_2018_final.pdf.

7. The Treaty of Maastricht or the European Union. 1992. URL : http://www.historiasiglo20.org/europe/maastricht.htm.

8. Про вплив політики державних запозичень та податкової політики на стан грошово-кредитної сфери України : Рішення Ради 
НБУ від 28.04.2020 №10-рд. URL : https://bank.gov.ua/ua/legislation/ Decision_28042020_10-rd.

9. Про діяльність Правління Національного банку України щодо виконання Основних засад грошово-кредитної політики в 2019 році : Рішення Ради НБУ від 25.02.2020 №4-рд. URL : https://bank.gov.ua/ua/ legislation/Decision_25022020_4-rd.

10. Про взаєморозуміння та співробітництво між Національним банком України, Національною комісією з цінних паперів та фондового ринку, Національною комісією, що здійснює державне регулювання у сфері ринків фінансових послуг, Фондом гарантування вкладів фізичних осіб та Міністерством фінансів України 3 питань підготовки та впровадження стратегії розвитку фінансового сектору України до 2025 р. : Меморандум від 28.05.2019 №101215. URL : https://zakon.rada.gov.ua/ laws/show/n0397500-19.

11. Про Рекомендації парламентських слухань на тему: «Актуальні питання зовнішньої політики України» : Постанова Верховної Ради України від 24.05.2017 №2069-VIII. URL : https://zakon.rada.gov.ua/laws /show/2069-19.

12. Про Звернення Верховної Ради України до інституцій Європейського Союзу щодо поглиблення співробітництва між Україною та Європейським Союзом : Постанова Верховної Ради України від 05.07.2018 №2490-VIII. URL : https://zakon.rada.gov.ua/laws /show/2490-19.

13. Стратегія макропруденційної політики НБУ (затверджена Правлінням НБУ в листопаді 2018 р.). URL : https://old.bank.gov.ua/ doccatalog/document?id=83019081.

14. Даниленко А. Що таке фінансова стабільність, та як центральні банки можуть іiі забезпечувати. URL : https://expla.bank.gov.ua/expla/ news_0026.html.

15. Методичні рекомендації щодо розрахунку рівня економічної безпеки України : Затверджено Наказом Міністерства економічного розвитку та торгівлі України 29.10.2013 №1277. URL : search.ligazakon. ua/1_doc2.nsf/link1/ME131588.html.

16. Методичні рекомендації щодо розрахунку рівня економічної безпеки України : Затверджено Наказом Міністерства економіки України 02.03.2007 №60. URL : http://consultant.parus.ua/?doc=03WN62 B99B.

17. Листи Міністерства розвитку економіки, торгівлі та сільського господарства України про надання інформації щодо інтегрального індексу економічної безпеки на запити про публічну інформацію від 24.04.2019 №3032-06/17571-09 та від 09.04.2020 №3032-06/23836-09.

18. Robert E. G. The Theory of Institutional Design, edited by Robert E. Goodin, Cambridge University Press. 1996.

19. Josep M. Colomer. Institutional Design. Prepared for: Handbook of Comparative Politics Todd Landmann and Neil Robinson eds. Sage, 2008. P. 246-262. 
20. David L. W. Institutional Design, edited by David L. Weimer, Kluwer Academic Publishers. 1995.

21. Пайманова В. А. Інституційний дизайн ринку капіталів як економічна категорія. Бізнесінформ. 2014. №7. С. 23-27.

22. Бунецький Л. Л. Інституційний дизайн сучасної української політики: криза ідентичності та конфлікт інтересів. Сучасна украӥнська політика. Політики і політологи про неї. К., 2010. Вип. 19. С. 120-136.

23. Про затвердження Технічного регламенту щодо встановлення системи для визначення вимог з екодизайну енергоспоживчих продуктів : Постанова Кабінету Міністрів України від 03.10.2018 №804. URL : https://zakon.rada.gov.ua/laws/show/804-2018-\%D0\%BF.

24. European Commission, «Communication from the Commission: Annual Sustainable Growth Strategy 2020». 2019. URL : https://eur-lex. europa.eu/legal-content/EN/TXT/?qid=1578392227719\&uri=CELEX\%3A5 2019DC0650.

25. European Commission, «Report from the Commission: Alert mechanism report 2020». 2019. URL : https://eur-lex.europa.eu/legal-content/ $\mathrm{EN} / \mathrm{TXT} /$ ?qid=1578392070452\&uri=CELEX\%3A52019DC0651.

26. Eurostat, Macroeconomic Imbalance Procedure Scoreboard. URL : https://ec.europa.eu/eurostat/documents/2995521/10266449/2-17122019BP-EN.PDF.

27. European Commission, «Communication from the Commission. 2020 European Semester: Assessment of progress on structural reforms, prevention and correction of macroeconomic imbalances, and results of indepth reviews under Regulation (EU) №1176(2011)». URL : https://eurlex.europa.eu/legal-content/EN/TXT/?qid=1584543632863\&uri=CELEX\% 3A52020DC0150.

28. European Commission, «Communication from the Commission on the 2020 Draft Budgetary Plans: Overall Assessment». 2019. URL : https://ec.europa.eu/info/sites/info/files/economy-finance/comm_chapeau_ 201119.pdf.

29. European Commission, «Recommendation for a Council recommendation on the National Reform Programme and delivering a Council opinion on the Stability Programme». 2019. URL : https://ec.europa.eu/info/ publications/2019-european-semester-country-specific-recommendationscommission-recommendations_en.

30. European Commission, «Proposal for a joint employment report from the commission and the council». 2020. URL : https://eur-lex.europa. eu/legal-content/EN/TXT/?qid=1578392632182\&uri=CELEX\%3A52019D C0653.

31. Official Journal of the European Union, «Regulation (EU) №1174/2011 on enforcement measures to correct excessive macroeconomic 
imbalances in the euro area». 2011. URL : https://eur-lex.europa.eu/legalcontent/EN/ALL/?uri=CELEX:32011R1174.

32. European Commission (2020), «National Reform Programme and Stability/Convergence Programme». 2020. URL : https://ec.europa.eu/ info/business-economy-euro/economic-and-fiscal-policy-coordination/eueconomic-governance-monitoring-prevention-correction/european-semester/ european-semester-timeline/national-reform-programmes-and-stabilityconvergence-programmes/2020-european-semester_en.

33. Проєкт Указу Президента України Про рішення Ради національної безпеки та оборони України «Про схвалення Положення про систему індикаторів (показників) стану національної безпеки України» від 2015 року та Проєкт Указу Президента України Про рішення Ради національної безпеки та оборони України «Про схвалення Положення про систему індикаторів (показників) стану національної безпеки України» від 2018 року. URL : https://www.rada.gov.ua.

34. Бюджетний кодекс України : Закон України від 08.07.2010 p. №2456-VI. Відомості Верховної Ради Украӥни (ВВР). 2010. №50-51. URL : http://zakon3.rada.gov.ua/laws/show/2456-17. 